\title{
Mastering evidence and proof: a tribute to Mike Redmayne
}

\author{
Paul Roberts \\ School of Law, University of Nottingham, UK \\ Email: paul.roberts@nottingham.ac.uk \\ Jonathan Doak \\ Nottingham Law School, Nottingham Trent University, UK
}

Email: jonathan.doak@ntu.ac.uk

This Special Issue of the International Journal of Evidence and Proof pays tribute to the scholarship of Mike Redmayne, who died last year at the age of only 47 (Roberts, 2015; Modern Law Review, 2015). During the past two decades, when we were privileged to call Mike our colleague, collaborator, co-author and friend, he produced a formidable corpus of scholarship spanning a great variety of topics in evidence, proof and criminal procedure. The contributors to this Special Issue celebrate Redmayne's scholarly legacy in a way that will ensure its continuing influence, and which--incidentally--would have been wholeheartedly endorsed by the man himself; that is, by engaging critically with Redmayne's arguments, following up his tentative suggestions for further exploration and developing the ideas and debates which Redmayne's extensive publications did so much to stimulate, enliven and enlighten. Whilst necessarily selective in their topical focus and not afraid to express criticisms and contrary opinions, the following seven essays and reviews are united in illuminating the breadth, originality and perspicuity of Redmayne's evidentiary scholarship.

In the opening article, Hamish Stewart revisits the perplexing topic of the privilege against self-incrimination. Despite its venerable common law heritage and recent reinvigoration as an integral part of the right to a fair trial in international human rights law, identifying a convincing normative rationale for the privilege is no simple task (see further, Roberts and Zuckerman, 2010: chapter 13). In one of his most imaginative contributions, Redmayne proposed a novel rationale for the privilege against self-incrimination rooted in the (liberal) value of dissociating oneself from state prosecutions (Redmayne, 2007a). Stewart questions whether the argument can succeed without a more structured approach to balancing competing values, which Redmayne's account cannot avoid without sacrificing its institutional plausibility. Whilst praising Redmayne's argument for its humanity, creativity and practicality, Stewart suggests that a richer account of criminal procedure linking the privilege against self-incrimination with the presumption of innocence may achieve a superior reconciliation between criminal adjudication and its underlying moral and political rationales.

The right to confrontation is another potent witches' brew of common law tradition, human rights law and deeper normative obscurity that attracted Redmayne's critical attentions (Redmayne, 2012a, 2012b), and is the subject of Liz Heffernan's contribution to this Special Issue. Redmayne intervened in the debate shortly after the Grand Chamber of the European Court of Human Rights issued its eagerlyanticipated judgment in Al-Khawaja. 1 
Heffernan reviews the "Al-Khawaja saga' and brings it up to date with the Horncastle 2 applicants' recent, unsuccessful, visit to Strasbourg. $\underline{3}$ Tensions between orthodox common law thinking about admissible hearsay and the notion of a procedural right to confront (whether articulated on the pattern of the US Sixth Amendment, or in the more equivocal language of ECHR Art $6(3)(d)) \underline{4}$ are central to this discussion. Heffernan praises Redmayne's interpretation of the confrontation right for its pragmatism and elegance, but also notes its vulnerability to attack for being too narrow in some contexts - too easily permitting convictions to rest on the evidence of absent witnesses--but too broad in others, for example, in failing to have sufficient regard for the dignitarian interests of crime victims and vulnerable witnesses. As is evident from subsequent case law, $\underline{5}$ the doctrinal contours of an ECHR-compliant right of confrontation are still far from settled. But the factors insightfully discussed by Redmayne will continue to frame ongoing debates.

The third article in this Special Issue, by Cheng and Nunn, shifts gears and takes us onto different terrain. One of Redmayne's principal--arguably his greatest--contributions to British Evidence scholarship was his pioneering role in emphasising systematic analysis of inferential reasoning as a necessary supplement to the elucidation and critique of exclusionary rules (see, for example, Redmayne, 1999, 2003a, 2003b, 2007, 2008a). A major strand of this research programme involved popularising and developing debates on forensic probability that, prior to Redmayne's decisive interventions (including Redmayne, 1995, 1997, 1998, 2001, 2003c; Redmayne and Allen, 1997), had made little impact on this side of the Atlantic. Cheng and Nunn propose an ingenious solution to a very well-known puzzle concerning proof by "naked statistical evidence'. When Redmayne himself reviewed the so-called "proof paradoxes' (see Feinberg, 1986; Kaye, 1979), in one of the most lucid discussions to be found anywhere in a voluminous literature on this mind-bending topic, he was forced to conclude that no entirely satisfactory, integrated account could be offered (Redmayne, 2008b). Cheng and Nunn, however, present an approach, rooted in statistical science, which enables them to convert continuous probabilities into dichotomous, categorical conclusions without--they claim--arbitrariness in the choice of thresholds. To readers unfamiliar with this style of literature or frightened of anything with numbers or graphs, the argument may appear abstruse and scholastic. In fact, it addresses the structural logic underpinning all scientific 6 evidence, including DNA profiling; and if Cheng and Nunn are right, their argument for what they dub "DNA exceptionalism' could have major practical implications for the way in which scientific and other expert evidence is written up and presented to fact-finders in criminal trials (cf. Cole and Roberts, 2012; Saks and Koehler, 2005, 2008).

Bad character evidence was one of Redmayne's enduring preoccupations, and the subject of his last major work, a monograph on Character in the Criminal Trial (CitCT) (Redmayne, 2015; also Redmayne, 1999, 2002a, 2002b, 2008c, 2011). The quartet of contributions completing this Special Issue make this fascinating and complex topic their focus. Federico Picinali addresses theoretical aspects of the common law's traditional hostility towards evidence of the accused's extraneous misconduct, which Redmayne, somewhat controversially, called into question. 7 According to one view, which Redmayne rejected, bad character evidence is problematic because it denies the autonomy of the accused by treating people as though they are incapable of breaking their bad habits. $\underline{8}$ Amit Pundik has recently attempted to revive and develop this line of argument, introducing some metaphysical big guns from philosophies of free will, determinism and causation into the 
evidentiary fray (Pundik, 2008, 2015). Picinali is underwhelmed. He argues in reply that the diversion into metaphysical territory does not produce the conclusions that Pundik asserts or requires, and that Redmayne's original rejection of autonomy-based objections to bad character evidence emerges from this stern theoretical re-examination unscathed. For Picinali (as for Sherlock Holmes), drawing inferences from generalisations about character is a more complex and contested enterprise than any reductive appeal to the value of autonomy could adequately grasp. Be that as it may, one thing is virtually certain: we are only in the midst of this lively debate, which has every appearance of enduring vitality.

Redmayne frequently credited David Hamer's penetrating analyses of character-based inferential reasoning as a formative influence on his own scholarship. Hamer's contribution to this Special Issue recapitulates the account that he developed over a series of articles to impose structure and order on the chaos of common law "similar facts' jurisprudence (see in particular Hamer, 2003). Hamer carefully classifies and dissects the patterns of inferential reasoning which character evidence may logically support, and relates them to the variety of legal frameworks governing the admissibility and legitimate (and illegitimate) uses of such information in criminal trials and the policy rationales underpinning evidentiary doctrines. His approach is in the spirit of "common law comparativism' (a method elucidated in Roberts and Hunter, 2012), extrapolating from a core common law tradition which, in modern times, has been adapted and refined in particular jurisdictions to produce idiosyncratic doctrinal variations, often partly as a result of systematic statutory reform. Hamer's synoptic analysis encompasses relevant provisions of the US Federal Rules of Evidence, Australia's Uniform Evidence Law, New Zealand's Evidence Act 2006 and the post-Criminal Justice Act 2003 bad character evidence law of England and Wales, noting many doctrinal intricacies, conceptual difficulties and competing conceptions of common law orthodoxy along the way. Hamer's objectives are diagnostic rather than programmatic. Adopting a methodological posture which Redmayne also found conducive, he suggests that greater analytical clarity might at least ease some of the law's most troublesome symptoms without, however, promising any miracle cures for complex conditions.

In the first of our pair of reviews of CitCT (also see Roberts, 2016), Jill Hunter demonstrates the value of interdisciplinary approaches to evidentiary questions. In particular, she situates the uses of (bad) character evidence in the historical evolution of modern English criminal trials, before revisiting some of the psychological research on character and conduct that Redmayne also discusses in his monograph (Redmayne, 2015: chapters 2-3). Attention to legal history supplies an important corrective to any blithe assumptions about the common law's supposed hostility in practice to receiving bad character evidence. In reality, character evidence has plainly been central to criminal adjudication in England and Wales for as long as anybody can remember, and the juridical logic of character-based fact-finding was extended to cross-examination of the accused in person under the Criminal Evidence Act 1898 (itself now an historical detail remote from the experience of law graduates in the post-Criminal Justice Act 2003 era). In relation to psychological data, Hunter stresses the range of situational factors that apparently affect recidivism rates, for example in terms of gender differentials. The implication may be that extraneous misconduct evidence is not safe to go to the jury unless jurors are also supplied with additional contextual information about the individual accused to enable them to use it 
properly. Besides, notes Hunter, extensive research on "biases and heuristics' cautions against the ease with which human beings may be cognitively hard-wired to reason stereotypically from very incomplete information (also see Cunliffe, 2014; Ellison and Munro, 2015). In conclusion, Hunter firmly endorses Redmayne's interdisciplinary methods and applauds the quality of his scholarship and forensic argumentation, but cannot accept the drift of his policy conclusions. It is perhaps worth adding that the theses advanced in CitCT are themselves often stated with reservation or significantly qualified, $\underline{9}$ so the distance between Hunter and Redmayne should not be exaggerated, even on the central question of the admissibility of propensity evidence in criminal trials.

Finally, Aparna Rao's pithy book review wraps up this Special Issue with some observations from the frontline of criminal advocacy. As she notes, CitCT is not intended to be a textbook for legal *E. \& P. 92 practitioners, but it still has much to offer criminal litigation in terms of conceptual analysis and doctrinal criticism. Redmayne was first and foremost a scholar and a teacher, but this does not mean that he lacked practical interests or concerns about the law in action. As an active and valued member of the Royal Statistical Society's Working Group on Statistics and the Law, 10 for example, Redmayne lent his shoulder to the wheel of communicating the logic of probabilistic reasoning to practitioner audiences (Redmayne et al., 2011; Roberts et al., 2011a, 2011b, 2015a, 2015b). In similar vein, his explorations of the privilege against self-incrimination, confrontation and hearsay, relevance, expert evidence and the law of bad character are as much concerned with the practical realities of criminal adjudication and the normative development of evidence law as they are lasting contributions to a theoretical jurisprudence.

It is time for the contributors to this Special Issue to speak for themselves. They do so from five jurisdictions 11 across three continents, and if geographical spread had been an editorial ambition we could easily have recruited further contributions from leading Evidence scholars based in Africa, Asia and Latin America. Mike Redmayne was a scholar of truly global stature, and his scholarship will illuminate the world of Evidence and Proof for many years to come.

Callen C (2007) Interdisciplinary and comparative perspectives on hearsay and confrontation. In: Roberts $\mathrm{P}$ and Redmayne M (eds) Innovations in Evidence and Proof. Oxford: Hart.

Cole SA and Roberts A (2012) Certainty, individualisation and the subjective nature of expert fingerprint evidence. Crim $L R 824$.

Cunliffe E (2014) Judging, fast and slow: Using decision-making theory to explore judicial fact determination. International Journal of Evidence and Proof 18(2): 139-180.

Ellison L and Munro VE (2015) "Telling tales': Exploring narratives of life and law within the (mock) jury room. Legal Studies 35(2): 201-225.

Feinberg SE (1986) Gatecrashers, blue buses, and the Bayesian representation of legal evidence. Boston University Law Review 66: 693-699.

Friedman RD (1998) Thoughts from across the water on hearsay and confrontation. Crim $L R 697$.

Hamer D (2003) The structure and strength of the propensity inference: Singularity, linkage and other evidence. Monash University Law Review 29: 137. 
Jackson J and Summers S (2013) Confrontation with Strasbourg: UK and Swiss approaches to criminal evidence. Crim $L R 115$.

Kaye DH (1979) The paradox of the gate-crasher and other stories. Arizona State LJ 101. Modern Law Review (2015) Obituary: Mike Redmayne. Modern Law Review 78(5): 727-728.

O'Brian WE, Jr (2005) The right of confrontation: US and European perspectives. Law Quarterly Review 121(3): 481-510.

Pundik A (2008) Statistical evidence and individual litigants: A reconsideration of Wasserman's argument from autonomy. International Journal of Evidence and Proof 12(4): 303-324.

Pundik A (2015) Freedom and generalizations. 28 January 2015, Available at: http://ssrn.com/abstract=2556690 (accessed 4 March 2016).

Redmayne M (1995) Doubts and burdens: DNA evidence, probability and the courts. Crim $L R 464$.

Redmayne M (1997) Presenting probabilities in court: The DNA experience. International Journal of Evidence and Proof 1(4): 187-214.

*E. \& P. 93 Redmayne M (1998) Bayesianism and proof. In: Freeman M and Reece H (eds) Science in Court. Aldershot: Ashgate.

Redmayne M (1999) A likely story! Oxford Journal of Legal Studies 19(4): 659-672.

Redmayne M (2001) Expert Evidence and Criminal Justice. Oxford: OUP.

Redmayne M (2002a) The relevance of bad character. Cambridge Law Journal 61(3): 684-714.

Redmayne M (2002b) The Law Commission's character convictions. International Journal of Evidence and Proof 6(2): 71-93.

Redmayne M (2003a) Myths, relationships and coincidences: The new problems of sexual history. International Journal of Evidence and Proof 7(2): 75-101.

Redmayne M (2003b) Rationality, naturalism, and evidence law. Michigan State Law Review 4: 849-884.

Redmayne M (2003c) Objective probability and the assessment of evidence. Law, Probability and Risk 2: 275-294.

Redmayne M (2007a) Rethinking the privilege against self-incrimination. Oxford Journal of Legal Studies 27(2): 209-232.

Redmayne M (2007b) Analysing evidence case law. In: Roberts P and Redmayne M (eds) Innovations in Evidence and Proof. Oxford: Hart.

Redmayne M (2008a) English warnings. Cardozo Law Review 30(3): 1047-1089.

Redmayne M (2008b) Exploring the proof paradoxes. Legal Theory 14(4): 281-309.

Redmayne M (2008c) The ethics of character evidence. Current Legal Problems 61(1): 
371-391.

Redmayne M (2011) Recognising propensity. Crim LR 177.

Redmayne M (2012a) Confronting confrontation. In: Roberts P and Hunter J (eds) Criminal Evidence and Human Rights. Oxford: Hart.

Redmayne M (2012b) Hearsay and human rights: Al-Khawaja in the Grand Chamber. Modern Law Review 75(5): 865-878.

Redmayne M (2015) Character in the Criminal Trial. Oxford: OUP.

Redmayne M and Allen R (eds) (1997) Bayesianism and juridical proof. International Journal of Evidence and Proof 1(5): 253-360.

Redmayne M, Roberts P, Aitken C and Jackson G (2011) Forensic science evidence in question. Crim LR 347.

Roberts P (2015) Mike Redmayne 1967-2015 International Journal of Evidence and Proof 19(4): 207-208.

Roberts P (2016) Redmayne's character and criminal jurisprudence. Modern Law Review 78: forthcoming.

Roberts P and Aitken C (2014) The Logic of Forensic Proof: Inferential Reasoning in Criminal Evidence and Forensic Science. RSS Practitioner Guide No 3. London: Royal Statistical Society. Available at www.rss.org.uk/statsandlaw (accessed 8 February 2016).

Roberts P and Hunter J (2012) Introduction: The human rights revolution in criminal evidence and procedure. In: Roberts $\mathrm{P}$ and Hunter J (eds) Criminal Evidence and Human Rights. Oxford: Hart.

Roberts P and Zuckerman A (2010) Criminal Evidence. 2nd edn. Oxford: OUP.

Roberts P, Aitken C, Jackson G, et al. (2011a) When the numbers count-Part 1. Criminal Law and Justice Weekly 175: 304.

Roberts P, Aitken C, Jackson G, et al. (2011b) When the numbers count-Part 2. Criminal Law and Justice Weekly 175: 319.

Roberts P, Aitken C and Jackson G (2015a) From admissibility to interpretation: New guidance on expert evidence. Criminal Law and Justice Weekly 179: 538.

*E. \& P. 94 Roberts P, Aitken C and Jackson G (2015b) From admissibility to interpretation: New guidance on expert evidence. Criminal Law and Justice Weekly 179: 564.

Saks MJ and Koehler JJ (2005) The coming paradigm shift in forensic identification science. Science 309(5736): 892-895.

Saks MJ and Koehler JJ (2008) The individualization fallacy in forensic science evidence. Vanderbilt Law Review 61(1): 199-219.

Tillers P (2005) If wishes were horses: Discursive comments on attempts to prevent individuals from being unfairly burdened by their reference class. Law, Probability and Risk $4(1-2): 33-49$. 
Wasserman DT (1991) The morality of statistical proof and the risk of mistaken liability. Cardozo Law Review 13: 935-976.

\section{Paul Roberts}

School of Law, University of Nottingham, UK

Email: paul.roberts@nottingham.ac.uk

Jonathan Doak

Nottingham Law School, Nottingham Trent University, UK

Email: jonathan.doak@ntu.ac.uk

1. Al-Khawaja and Tahery v United Kingdom (2012) 54 EHRR 23, ECtHR (GC).

2. $R$ v Horncastle [2010] 2 AC 373, [2009] UKSC 14.

3. Horncastle v United Kingdom (2015) 60 EHRR 31.

4. For instructive comparative analysis, see Jackson and Summers (2013); Callen (2007); O'Brian (2005); Friedman (1998).

5. $\quad$ See e.g. $R$ v Ibrahim [2012] 2 Cr App R 32, [2012] EWCA Crim 837; $R$ v Riat [2013] 1 Cr App R 2, [2012] EWCA Crim 1509.

6. This adjective is not meant to be exclusive. The same inferential logic in fact underpins all evidence, scientific or otherwise. See further, Roberts and Aitken (2014).

7. Redmayne argued that empirical data "do not support anything like a strict exclusionary rule for bad character evidence', and concluded that "arguments which have been put forward for a "moralized" exclusionary rule are unconvincing'. Consequently, the "best policy is ... to let fact-finders know about a defendant's previous convictions, at least when they are relevant to guilt' (2015: 60-61, 90).

8. See e.g. Wasserman (1991). Hamer also refers to this argument in his essay, infra. Cf. Tillers (2005).

9. Redmayne's approach is underwritten by the pragmatic expectation that "criminal trials are awash with character inferences whether we like it or not', and his endorsement of the CJA 2003's explicit support for propensity reasoning is coupled with approval of continuing judicial conservatism in receiving bad character evidence in criminal trials and candid acknowledgement of numerous risks and potential drawbacks (2015: 61, 167-172). Redmayne is also very critical of key provisions of the CJA 2003 permitting impeachment uses of bad character evidence (2015: ch. 9).

10. The Working Group, chaired by Professor Colin Aitken of Edinburgh University, subsequently graduated into a permanent Section of the RSS: www.statslaw.wordpress.com/about/.

11. Or six, if Picinali counts for Italy as well as England and Wales. 
